\title{
Comparison of Awareness and Perception of Climate Change between Proklim and Non- Proklim Farmers in Sleman District
}

\author{
Moh. Wahyudi Priyanto ${ }^{1}$, Jangkung Handoyo Mulyo ${ }^{2, *}$, and Irham $^{2}$ \\ ${ }^{1}$ Agricultural Economics, Faculty of Agriculture, Universitas Gadjah Mada \\ ${ }^{2}$ Departement of Agricultural Socioeconomics, Faculty of Agriculture, Universitas Gadjah Mada
}

\begin{abstract}
Program kampung iklim (Proklim) was launched by the Government to increase the implementation of the climate change adaptation strategy. The decision to adopt an adaptation strategy is influenced by farmers' perceptions of climate change. This study aims to determine the level and compare the awareness of the climate change and perceptions of the climate change risks, among farmers from the Proklim and non-Proklim locations. The study was conducted in 3 sub-districts that have Proklim location, in Sleman Regency. By using the simple random sampling method, a total of 112 farmers were selected from the Proklim and non-Proklim locations in the same proportion. The results showed that the Proklim and non-Proklim locations were dominated by farmers with an awareness of climate change and perceptions of climate change risks at a moderate level. Other findings showed that farmers from the Proklim location had a higher awareness of climate change compared with nonProklim farmers, with a difference of awareness of $6.44 \%$. Perceptions of climate change risk among farmers from the two locations didn't show significant differences.
\end{abstract}

\section{Introduction}

The phenomenon of climate change is getting serious attention at this time and will show changes that are getting worse in the future. Researchers predict that the global temperature in 2100 will increase in the range of $2.0-4.9^{\circ} \mathrm{C}$ [1], and rainfall will be stronger due to an increase in water vapor in the atmosphere [2]. The agricultural sector as the main livelihood of rural people is at high vulnerability due to climate change [3]. Climate change has a significant impact on crop productivity in the short and long term. Crop productivity will decrease even though the temperature has increased slightly [4]. Drought due to climate change causes the total factor of agricultural productivity (e.g.: the efficiency of using agricultural machinery) to decrease by $18 \%$ compared to pre-drought conditions [5]. Water resources available for agriculture will decrease due to climate change. The problem increases if there is an increase in water demand when there is a decrease in rainfall. It causes a decrease in the welfare of the farmers family [6]. Climate change has a negative

\footnotetext{
* Corresponding author: jhandoyom@gmail.com
} 
impact on Southeast Asian countries because the agricultural sector as one of the main economic sectors will be disrupted due to decreased productivity caused by climate change [7]. Smallholders are the most vulnerable because they have limited capital and use rainfed farming systems [8].

The negative impacts of climate change can be minimized by implementing adaptation strategies. The government provides support to increase the implementation of adaptation strategies by the community through the Program Kampung Iklim or Proklim which was passed in 2012. Proklim is a national program under the Ministry of Environment and Forestry (Kementerian Lingkungan Hidup dan Kehutanan) that was formed to increase adaptation capacity to climate change and reduce greenhouse gas emissions [9] one of which is by increasing awareness of phenomena and perceptions of climate change risks [10]. Proklim was formed on the basis of awareness of the negative impacts caused by climate change [11].

One of the decisions to implement an adaptation strategy is influenced by farmers' awareness of climate change and farmers' perceptions of climate change risks. It means that farmers with good perceptions tend to apply adaptation strategies [12]. Farmers with good perceptions show a better level of knowledge about the causes, impacts and ways to reduce the impacts of climate change [13]. Farmers in Yogyakarta stated that they felt changes in indicators of climate change including increased temperature, erratic rainfall, increased drought intensity, and erratic seasons [14]. Farmers are also aware that increasing climatic events such as floods, increasing summer temperatures, droughts, changing cropping calendars, and water scarcity will cause losses to agricultural output $[15,16]$.

Increasing public awareness and perceptions will not be possible without government and private intervention. All elements must work together and be committed, so that the goals can be achieved [17]. Support from the government and the private sector through the establishment of institutions such as farmer groups, extension activities, field school programs, climate-smart agriculture programs were found to be able to increase farmers 'awareness of climate change, farmers' perceptions of climate change risks, and the implementation of climate change adaptation strategies [18-23].

Many previous studies have modeled the impact of climate change on agricultural production. However, research on awareness of phenomena and perceptions of the impacts of climate change is not widely conducted [24]. Whereas, awareness of climate change and perceptions of climate change risks are factors that influence farmers to implement climate change adaptation strategies [23,25,26]. Important to know the level of awareness and perception of farmers and see whether the existence of Proklim can increase farmers' awareness and perceptions. Therefore, this study aims to 1) determine the awareness of farmers from Proklim to the phenomenon of climate change and perceptions of climate change risks, and 2) to know the comparison of awareness and perceptions among farmers from Proklim and farmers from non-Proklim.

\section{Method}

\subsection{Study area}

The research was conducted in December 2019 located in Sleman District by selecting 3 villages in 3 different sub-districts. Then 1 Proklim location and 1 non-Proklim location were selected from each village so that there were 3 Proklim locations and 3 non-Proklim locations in this study. Sleman District was chosen as the research location because there were 10 locations registered as Proklim participants. Besides, agriculture is the largest employer in the area. In 2018, there were 124,992 workers in the agricultural sector. The 
rice crop in Sleman District is a commodity with the largest proportion of land and production compared to other food crops. Based on the problem of climate indicators, Sleman District in 2008-2018 showed an increasing trend in climate indicators including maximum rainfall, wind speed, minimum temperature, and maximum temperature [27].

Table 1. Research locations

\begin{tabular}{|l|l|c|l|c|l|c|}
\hline \multirow{2}{*}{$\begin{array}{c}\text { Sub- } \\
\text { district }\end{array}$} & \multicolumn{1}{c}{ Location } & Pop. & \multicolumn{1}{c}{ Location } & Spl. & \multicolumn{1}{c|}{ Location } & Spl. \\
\hline Ngaglik & Sariharjo & 621 & Wonorejo & 16 & Karangmloko & 16 \\
\hline Sleman & Pandowoharjo & 851 & Karangtanjung & 20 & Karangasem & 20 \\
\hline Moyudan & Sumberagung & 1,524 & Pendulan & 20 & Kaliduren II & 20 \\
\hline
\end{tabular}

The sampling method used in this study was simple random sampling with a total sample of 112 farmers from a population of 2,996 farmers. Samples were divided proportionally from both Proklim location and non-Proklim location. Samples from each of the pro-climate and non-pro-climate locations were 56 farmers. Samples of farmers from Ngaglik is smaller than the sample of farmers from the other two sub-districts because the farmer population in that district is smaller.

\subsection{Likert scale weighting using the $Z$ distribution approach}

The Likert scale was used in this study to determine awareness of the phenomenon of climate change and farmers' perceptions of climate change risks. The scale of the answers to farmers' awareness of changes in climate indicators is 1 if the climate indicator has greatly decreased; 2 if decreases; 3 if constant; 4 if increases; and 5 if greatly increased. The answer scale for farmers' perceptions of climate change risk is 1 if strongly disagree; 2 if agree; 3 if undecided; 4 if agree; and 5 if strongly agree.

Table 2. Indicator questions for awareness of climate change and perceptions of climate change risks

\begin{tabular}{|l|l|}
\hline \multicolumn{1}{|c|}{ Farmers' awareness of climate change } & Farmers' perceptions of climate change risks \\
\hline $\begin{array}{l}\text { Comparison of temperatures during the current } \\
\text { dry season with 15 years ago. }\end{array}$ & $\begin{array}{l}\text { Increasing the temperature will increase the } \\
\text { drought. }\end{array}$ \\
\hline $\begin{array}{l}\text { Comparison of temperatures during the current } \\
\text { wet season with 15 years ago. }\end{array}$ & $\begin{array}{l}\text { The longer the dry season has an impact on } \\
\text { decreasing production. }\end{array}$ \\
\hline $\begin{array}{l}\text { Comparison of rainfall during the current dry } \\
\text { season with 15 years ago. }\end{array}$ & $\begin{array}{l}\text { Increased rainfall will cause an increase in pests } \\
\text { and diseases in crops. }\end{array}$ \\
\hline $\begin{array}{l}\text { Comparison of rainfall during the current wet } \\
\text { season with 15 years ago. }\end{array}$ & Increased rainfall will cause the land to flood. \\
\hline $\begin{array}{l}\text { Comparison of wind speed during the current dry } \\
\text { season with 15 years ago. }\end{array}$ & Increased wind speed will cause crop failure. \\
\hline $\begin{array}{l}\text { Comparison of wind speed during the current wet } \\
\text { season with 15 years ago. }\end{array}$ & $\begin{array}{l}\text { The erratic shifting of seasons has an impact on } \\
\text { decreasing rice productivity. }\end{array}$ \\
\hline $\begin{array}{l}\text { Comparison of the uncertainty of the arrival dry } \\
\text { and wet seasons today with 15 years ago. }\end{array}$ & $\begin{array}{l}\text { Extreme climatic events i.e. floods, droughts, } \\
\text { storms cause damage to humans. }\end{array}$ \\
\hline
\end{tabular}

The value of farmer awareness and perception is obtained from 7 question indicators (Table 2). Farmers 'answers to indicators cannot be added up to obtain the value of the farmers' awareness and perceptions, because the weight for each question depends on the distribution of answers. Besides, because the answers to the indicators are still in the form of a Likert scale (Ordinal scale). The scores of the indicators can be added up if the scores are converted into an interval or ratio scale by weighting the Likert scale using the $\mathrm{z}$ distribution approach. To obtain the value of awareness and perception of farmers in percentage units (\%), a z-score of the scale of 5 answers to the 7 question indicators was 
summed. Then the total value of farmer awareness and perception is divided by the highest total $\mathrm{z}$ score, then multiplied by $100 \%$.

The results of calculations using this method obtained the lowest awareness value of $25.02 \%$ and the highest awareness value of $88.88 \%$. The same calculation is also applied to obtain the value of farmers' perceptions of the climate change risks. The lowest perception value obtained was $42.94 \%$ and the highest perception value was $99.99 \%$. Farmers' awareness and perceptions are divided into 3 categories, namely low, medium and high.

\subsection{Two sample t-test}

Proklim and non-Proklim farmers were compared to assess differences in awareness of climate change and perceptions of climate change risks using a two-sample t-test analysis. The analysis was used by assessing the comparison of means among the two groups. The two groups must be independent or not influenced by each other. The requirements that must be fulfilled in the t-test analysis are having normal data distribution (normality) and having different variances among the two groups. The formula for the mean is shown by the function $\overline{X_{i}}[28]$,

$$
\overline{X_{i}}=\frac{1}{n_{i}} \sum_{j=1}^{n_{i}} X_{j}
$$

Where $\mathrm{i}=0,1$, dan $\mathrm{j}=1,2, \ldots, \mathrm{n}_{\mathrm{i}}$ is the observation of the two groups. The mean difference $\left(\overline{X_{d}}\right)$ among the two groups is $\overline{X_{d}}=\overline{X_{1}}-\overline{X_{0}}$. The hypothesis testing of mean among the two groups is shown by the following formula,

$$
T_{\text {test }}=\frac{X_{d}}{\sqrt{\left(\frac{1}{n_{0}}+\frac{1}{n_{1}}\right)} \frac{\left(n_{0}-1\right) s_{0}^{2}+\left(n_{1}-1\right) s_{1}^{2}}{n_{0}+n_{1}-2}}
$$

Where $n_{0}+n_{1}-2$ is the degree of freedom of the test (df), $s_{0}^{2}$ is the variance from group $0, s_{1}^{2}$ is the variance from group $1, n_{0}$ is the observation from group 0 , dan $n_{1}$ is the observation from group 1.

\section{Result and Discussion}

\subsection{Farmers' awareness of climate change}

Table 3 shows the distribution of farmers based on the category of awareness of climate change and t-test analysis to see the comparison of farmers' awareness of Proklim and nonProklim. The results showed that most farmers from Proklim and non-Proklim had moderate awareness. Focus on farmers' awareness of climate change in the high category, Proklim locations show a higher number of farmers than non-Proklim locations. This shows that farmers from program locations have a higher awareness than farmers from nonprogram locations. It is also proven by the results of the t-test analysis where farmers from Proklim had an average awareness of $63.15 \%$, while farmers from non-Proklim locations had an average awareness value of $56.71 \%$. The results of statistical tests showed that the difference in awareness among the two groups was $6.44 \%$ at a significance level above $99 \%$. So that farmers who come from program locations have a higher awareness of climate change that is happening. Following previous research which states that locations that do not implement the Climate-Smart Village program take more actions that make climate change worse and they do not realize that climate change is happening [29]. The existence 
of a program such as a Farmer field school makes farmers have a higher awareness than farmers who don't participate in the program [21].

Table 3. Comparison of the awareness of farmers in Proklim and non-Proklim locations to climate change phenomena

\begin{tabular}{|c|l|c|c|c|}
\hline & & Interval (\%) & Proklim (56) & Non-Proklim (56) \\
\hline \multirow{3}{*}{ Category } & Low & $25.02-46.30$ & $0 \%$ & $16.07 \%$ \\
\cline { 2 - 5 } & Moderate & $46.31-67.59$ & $78.57 \%$ & $71.43 \%$ \\
\cline { 2 - 5 } & High & $67.60-88.88$ & $21.43 \%$ & $12.50 \%$ \\
\hline \multirow{3}{*}{ T-test } & Mean & & 63.15 & 56.71 \\
\cline { 2 - 5 } & Std. deviation & & 9.54 & 12.02 \\
\cline { 2 - 5 } & Difference & & \multicolumn{2}{|c|}{$6.44^{* * *}(3.139)$} \\
\hline
\end{tabular}

*** shows the level of significance at the $1 \%$ level

Access to weather information is another factor that may cause farmer awareness of the Proklim location to be higher. Farmers in Proklim locations received more information on weather forecasts than farmers in non-Proklim locations with a percentage of $75 \%$ and $64.29 \%$ (Table 4). Farmers get weather forecast information from television, social media, extension agents, and farmer group discussions. Weather information is one of the factors that influence farmers' awareness of climate change. Farmers who received weather information were 8 times more aware than farmers who did not receive weather information [30]. Access to weather information through government services needs to be improved so that rural community awareness of climate change also increases. Increasing rural community awareness will further increase the implementation of climate change adaptation strategies [31].

Table 4. Distribution of farmers based on weather information obtained

\begin{tabular}{|c|c|c|}
\hline Weather information & Proklim (\%) & Non-Proklim (\%) \\
\hline Get information & 75.00 & 64.29 \\
\hline No information & 25.00 & 35.71 \\
\hline
\end{tabular}

\subsection{Farmers' perceptions of climate change risks}

Proklim and non-Proklim locations were dominated by farmers with moderate levels of perception of $52.79 \%$ and $46.43 \%$ (Table 5). It is interesting to discuss low and high farmers' perceptions of climate change risks. Proklim locations show more farmers in the low-risk perception category and fewer farmers in the high-risk perception category than farmers from non-Proklim. The results of the t-test analysis showed that there was no significant difference in perceptions of climate change risk among farmers from Proklim and non-Proklim locations. It can be seen from the t-value of 1.068 which is smaller than the t-table of 1.982. Moreover, farmers from non-Proklim have a higher perception than farmers from Proklim with a difference in perception of $2.43 \%$. This shows that the existence of Proklim doesn't make farmers perceptions of the climate change risks at a high level.

The reason that may cause the perception of non-Proklim farmers to be higher than that of Proklim farmers is the farmer's experience of crop failure (Table 6). Based on the interviews conducted, $33.92 \%$ of farmers from non-Proklim had experienced crop failure (rice yields failed completely), while only 19.64\% of farmers from Proklim had experienced crop failure. The cause of crop failure at the research location was due to rat pests, fallen rice plants due to wind and drought. Perceptions of climate change risk are formed from past experiences of being impacted by extreme climates [32]. Perceptions of climate change risks will increase as experiences of climate change risks increase [33]. 
According to other sources, climate change risk assessment is through a process of motivated reasoning that can be influenced by experiences affected by climate change [34].

Table 5. Comparison of farmers' perceptions of Proklim and non-Proklim locations on the climate change risk

\begin{tabular}{|c|l|c|c|c|}
\hline & & Interval (\%) & Proklim (56) & Non-Proklim (56) \\
\hline \multirow{3}{*}{ Category } & Low & $42.94-61.96$ & $19.64 \%$ & $16.07 \%$ \\
\cline { 2 - 5 } & Moderate & $61.97-80.98$ & $51.79 \%$ & $46.43 \%$ \\
\cline { 2 - 5 } & High & $80.99-99.99$ & $28.57 \%$ & $37.50 \%$ \\
\hline \multirow{3}{*}{ T-test } & Mean & & 73.56 & 75.99 \\
\cline { 2 - 5 } & Std. deviation & & 11.24 & 12.97 \\
\cline { 2 - 5 } & Difference & & \multicolumn{2}{|c|}{$-2.43(-1.068)$} \\
\hline
\end{tabular}

Table 6. Distribution of farmers based on crop failure experiences

\begin{tabular}{|c|c|c|}
\hline Crop failure & Proklim (\%) & Non-Proklim (\%) \\
\hline No & 80.36 & 66.08 \\
\hline Yes & 19.64 & 33.92 \\
\hline
\end{tabular}

\section{Conclusion and Recommendation}

Farmers from Proklim and non-Proklim had awareness of climate change at a moderate level. Farmers from Proklim locations show a higher awareness value than farmers from non-Proklim locations because they are influenced by the existence of Program Kampung Iklim and weather information obtained by farmers. Perceptions of climate change risks for Proklim and non-Proklim farmers also show a moderate level. The level of perception among farmers from the two locations didn't show a significant difference. The perception value of farmers from non-Proklim was higher than farmers from Proklim because more farmers from non-Proklim experienced crop failure (Rice yields failed completely) compared to farmers from Proklim.

The suggested policy implication is to expand the location of the Program Kampung Iklim (Proklim) because the research results show that the awareness of farmers from Proklim to climate change is higher than awareness of non-Proklim farmers. Access to weather information needs to be improved so that farmers' awareness and perceptions of climate change risks also increase. Suggestions for future researchers are to examine the impact of implementing adaptation strategies on farmer productivity and income.

Acknowledgements. The author would like to thank the Deputy for Strengthening Research and Development, Ministry of Research and Technology/National Research and Innovation Agency who has provided financial support for research and publication activities that the author undertakes.

\section{References}

1. A. E. Raftery, A. Zimmer, D. M. W. Frierson, R. Startz, and P. Liu, Nature Clim Change 7, 637 (2017).

2. M. Collins, R. Knutti, J. Arblaster, J.-L. Dufresne, T. Fichefet, X. Gao, W. J. G. Jr, T. Johns, G. Krinner, M. Shongwe, A. J. Weaver, and M. Wehner, Long-Term Climate Change: Projections, Commitments and Irreversibility. In: Climate Change 2013: The Physical Science Basis. Contribution of Working Group I to the Fifth Assessment Report of the Intergovernmental Panel on Climate Change (Cambridge University Press, Cambridge, United Kingdom and New York, NY, USA., 2013). 
3. A. W. Utami, I. Irham, J. H. Mulyo, and F. Rohmah, Asia-Pacific Journal of Rural Development 25, 17 (2015).

4. N. A. Abdallah, V. Moses, and C. Prakash, GM Crops \& Food 5, 77 (2014).

5. Y. Sheng and X. Xu, Economic Modelling 76, 182 (2019).

6. V. Karimi, E. Karami, and M. Keshavarz, Journal of Integrative Agriculture 17, 1 (2018).

7. S. K. Redfern, N. Azzu, and J. S. Binamira, in Building Resilience for Adaptation to Climate Change in the Agriculture Sector: Proceedings of a Joint FAO/OECD Workshop 23-24 April 2012, edited by A. Meybeck, J. Lankoski, S. Redfern, and N. Azzu (Food And Agriculture Organization Of The United Nations, Organisation for Economic Co-operation and Development, Rome, 2012), pp. 295-314.

8. C. A. Harvey, M. Saborio-Rodríguez, M. R. Martinez-Rodríguez, B. Viguera, A. Chain-Guadarrama, R. Vignola, and F. Alpizar, Agric \& Food Secur 7, 1 (2018).

9. KEMEN-LHK (Kementerian Lingkungan Hidup dan Kehutanan), Peraturan Menteri Lingkungan Hidup dan Kehutanan Republik Indonesia Nomor P. 84/ MENLHKSETJEN/ KUM.1/ 11/ 2016 Tentang Program Kampung Iklim (Direktorat Jenderal Peraturan Perundang-undangan, Jakarta, 2016).

10. A. E. Dewi, M. Maryono, and B. Warsito, E3S Web Conf. 125, 02002 (2019).

11. D. Faedlulloh, B. Irawan, and R. Prasetyanti, Publisia: Jurnal Ilmu Administrasi Publik 4, 28 (2019).

12. S. Li, L. Juhász-Horváth, P. A. Harrison, L. Pintér, and M. D. A. Rounsevell, Journal of Environmental Management 185, 21 (2017).

13. M. K. Saha, A. A. A. Biswas, J. Meandad, R. Ahmed, J. Prokash, and F. M. Sakib, 4, 113 (2019).

14. Irham, O. Saito, H. Mohri, G. Wirakusuma, F. Rohmah, and H. Perwitasari, in Resilient Asia, edited by K. Takeuchi, O. Saito, H. Matsuda, and G. Mohan (Springer Japan, Tokyo, 2018), pp. 81-94.

15. M. Abid, J. Schilling, J. Scheffran, and F. Zulfiqar, Science of The Total Environment 547, 447 (2016).

16. G. M. M. Alam, K. Alam, and S. Mushtaq, Climate Risk Management 17, 52 (2017).

17. R. Chhetri and S. Adhikari, JFET 13, 42 (2018).

18. U. Khanal, C. Wilson, V.-N. Hoang, and B. Lee, Ecological Economics 144, 139 (2018).

19. C. Ragasa and J. Mazunda, World Development 105, 25 (2018).

20. M. K. Hasan and L. Kumar, Journal of Environmental Management 237, 54 (2019).

21. J. Tomlinson and K. Rhiney, J Environ Stud Sci 8, 86 (2018).

22. V. O. Abegunde, M. Sibanda, and A. Obi, Sustainability 12, 1 (2020).

23. G. Mustafa, I. A. Latif, M. K. Bashir, M. N. Shamsudin, and W. M. N. W. Daud, Applied Environmental Education \& Communication 18, 219 (2019).

24. A. Ayanlade, M. Radeny, and J. F. Morton, Weather and Climate Extremes 15, 24 (2017).

25. N. W. M. G. S. Navaratne, W. A. D. P. Wanigasundera, and P. C. B. Alahakoon, AJAEES 36, 1 (2019).

26. A. Sb, M. Kr, and A. Ma, in Proceedings of ISER 99th International Conference (New York, 2018), pp. 6-13. 
27. BPS Sleman, Kabupaten Sleman Dalam Angka 2019 (BPS Kabupaten Sleman, Sleman, DIY, 2019).

28. M. Xu, D. Fralick, J. Z. Zheng, B. Wang, X. M. Tu, and C. Feng, Shanghai Archives of Psychiatry 29, 184 (2017).

29. S. Khanal, R. A. Mandal, and A. Nepal, ARTOAJ 20, (2019).

30. A. M. Ado, J. Leshan, P. Savadogo, L. Bo, and A. A. Shah, Environ Dev Sustain 21, 2963 (2019).

31. N. Debela, C. Mohammed, K. Bridle, R. Corkrey, and D. McNeil, SpringerPlus 4, 1 (2015).

32. A. Eitzinger, C. R. Binder, and M. A. Meyer, Climatic Change 151, 507 (2018).

33. P. Asrat and B. Simane, Ecol Process 7, 1 (2018).

34. H. Mitter, M. Larcher, M. Schönhart, M. Stöttinger, and E. Schmid, Environmental Management 63, 804 (2019). 